\title{
INVESTIGATING THE NIGHTTIME URBAN HEAT ISLAND (CANOPY LAYER) USING MOBILE TRAVERSE METHOD: A CASE STUDY OF COLON STREET IN CEBU CITY, PHILIPPINES
}

\author{
${ }^{1}$ Rowell Ray Lim SHIH, ${ }^{2}$ István KISTELEGDI \\ ${ }^{1}$ University of San Carlos, Cebu, Philippines, e-mail: rowellshih@yahoo.com \\ ${ }^{2}$ Department of Building Structures and Energy Design, Faculty of Engineering and \\ Information Technology, University of Pécs, Boszorkány u. 2, H-7624 Pécs, Hungary \\ e-mail: kistelegdisoma@mik.pte.hu
}

Received 8 August 2016; accepted 21 April 2017

\begin{abstract}
Rapid urbanization has resulted in temperature differences between the urban area and its surrounding areas. Academics have called this as the urban heat island phenomenon. Among the places that have seen rapid urbanization is the City of Cebu. The Philippine's oldest street, Colon, was chosen as the study area due to the near absence of vegetation and closely spaced buildings. Buildings that are spaced more closely as well as multiple absorptions and reflections produce higher and more viable street temperatures. This study tries to systematically understand the urban heat island effect between Colon and Lawaan, the rural area defined in this study. In order to quantify the urban heat island between two given locations, the mobile traverse method during the summer time, for a 10-day period in May 2016. A digital thermometer measuring platform was mounted on top of a vehicle to measure the different temperatures of Colon Street. Urban temperatures were also gathered in the Lawaan area using the same device. Preliminary results showed the presence of the urban heat island phenomenon between the two areas $\left(\Delta T=1.17^{\circ} \mathrm{C}\right)$. The provision of green spaces and proper urban planning are essential in mitigating future urban heat stress due to anthropogenic changes of existing cities.
\end{abstract}

Keywords: Urban heat island, Colon Street, Urban temperatures, Mobile traverse, Urbanization

\section{Introduction}

Majority of the world's population is now living in urban environments. More than half of the world's population now live in urban areas and this number is estimated to be around $67 \%$ in the year 2030 [1]. Worldwide urban land is now expanding at almost twice the population growth rate and this is expected to triple by year 2030 [2]. Due to 
the conversion of forested areas, the average temperature of these developed areas is now higher than the surrounding rural area. This is a phenomenon popularity known as the Urban Heat Island (UHI) [3]. UHI is defined by researchers as the temperature difference between urban and rural areas and was observed to be more evident in summer than during the day [4]-[8]. Ever since the first methodical urban heat island study conducted by Luke Howard in the city of London at the beginning of the $19^{\text {th }}$ Century [9], it remains a topic of research in different cities and climates. The UHI has a typical daily cycle [10], [11] as it increases during the late afternoon and reaches its maximum during the night, decreasing after dawn and generally reaching a minimum value during the morning. The typical UHI measurements have taken two approaches: temperature observations at fixed stations located in urban and rural environments and temperature measurements along transect from the city center to the rural environment using a mobile platform. Both of these studies evaluate the UHI by comparing the urban $(U)$ observations with rural $(R)$ or background temperatures $\left(\Delta T_{U-R}\right)$. Some factors like the increase of anthropogenic heat or modifications in vegetative cover during the year contribute to the urban heat island phenomenon [12]-[17]. Sharifi and Lehmann [18] further discussed how taller buildings tend to produce higher street temperatures due to multiple reflections and absorptions of radiation, a situation more compounded when the locations of urban buildings are closely spaced. Slingerland [19] shows the difference between an urban area and a small park can be as much as $3{ }^{\circ} \mathrm{C}$ by using temperature sensors. The study also showed the UHI intensity is largest during the night and can be up to $7{ }^{\circ} \mathrm{C}$. Sarkar and De Ridder [20] reports how during the night, low wind speeds, limited cloud cover and precipitation favors the development of urban heat island. Numerous studies have also shown that the UHI is negatively correlated with wind speed and cloud cover [21], [10]. Voogt [22] has shown that there are three types of UHI: The Canopy Layer Urban Heat Island (CLUHI); Boundary Layer Urban Heat Island (BLUHI) and the Surface Urban Heat Island (SUHI). The main focus of this study is the Canopy Layer, which is found within the atmosphere below the tops of buildings and trees [3]. The Canopy Layer UHI is a local scale phenomenon and given its accessibility and relevance to human activities, it is the most studied of all heat island types [12]. However, very few studies have focused in the urban climate of the City of Cebu. The main objective of this study is to investigate the UHI trends between urban-rural areas and determine the maximum and minimum temperature differences during the summer nights. While the climatological description of a city is based on a fixed meteorological station, which is usually fixed in the airport (rural area), it is not a representative of the whole city due to its location [23]. Temperature at the airport can have different reading in the middle of an urbanized area [24]. This study sets out to measure the intensity of the UHI using the mobile transect method. Using the mobile traverse as a method to measure the urban heat island appeared in many studies in literature [24]-[30].

\subsection{Study area}

The study area of this research is the Philippines oldest street, Colon, which is located in the island of Cebu. Colon was chosen as the urban study area because the region has developed into an urban landscape, which is almost absent of natural 
vegetation. Furthermore, Colon's urban morphology of closely spaced buildings, the high volume of vehicles and a high number of human activity can result in an urban climate different from that of the surrounding landscapes [17]-[20]. Colon Street is around 1.15 kilometers long and is located in the heart of the City of Cebu. A monument obelisk marks the start Colon Street and then ends at the intersection of Panganiban Street. Over the years, Colon has developed as the main Commercial Business District (CBD), which is roughly 7.62 meters above sea level (Table I). The municipality of Lawaan was chosen as the outlying rural area for comparison because of an ominously lesser amount of human and vehicular traffic, a profuse amount of natural vegetation and the distance between Colon is around 25 minute (9 kilometers apart, Fig. 1). In doing a UHI traverse study, the distance between two temporal zones must be less than $45^{\circ} \mathrm{C}$ before significant temperature changes between the two areas can be perceived [28], [29]. The altitude difference between Lawaan and Colon is around 14.58 meters, which is an important aspect to consider in studying UHI phenomenon. Altitudinal differences between the urban and rural points should never surpass 30 meters as this would represent in a substantial temperature differences in the calculating the intensities of the heat island [31].

\section{Table I}

Elevation and Distance between Colon (urban) and Lawaan (rural) area

\begin{tabular}{|c|c|c|c|}
\hline Location & Elevation $(\mathrm{M})$ & Latitude & Longitude \\
\hline Colon & 7.62 & $10^{\circ} 17^{\prime} 52.11^{\prime \prime} \mathrm{N}$ & $123^{\circ} 54^{\prime} 7.22^{\prime \prime} \mathrm{E}$ \\
\hline Lawaan & 22.2 & $10^{\circ} 15^{\prime} 35.03^{\prime \prime} \mathrm{N}$ & $123^{\circ} 54^{\prime} 7.22^{\prime \prime} \mathrm{E}$ \\
\hline
\end{tabular}

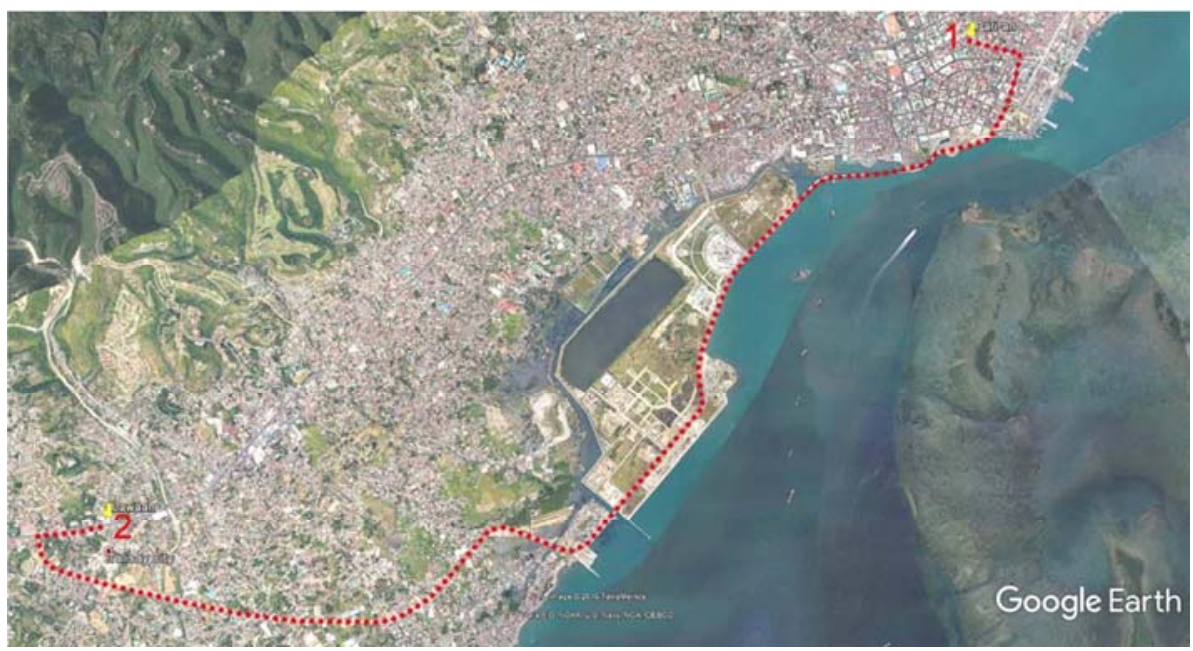

Fig. 1. Map of Talisay City and Cebu City, Cebu, From: 'Map of Central Visayas', $10^{\circ} 16^{\prime} 32.08^{\prime \prime N} 123^{\circ} 52^{\prime} 14.91 " E$. Google Earth, Accessed January 10, 2017 ,

Retrieved January 31, 2017, Mobile UHI transect from point 1 (Colon) to point 2 (Lawaan) 


\section{Materials and methods}

The mobile traverse method was used in this study to investigate the UHI phenomenon of the City of Cebu, particularly the Commercial Business District (CBD) of Colon. The data on air temperature were collected on ten occasions using mobile traverse surveys during the summer month of May 12-23 2016 between 20:00-21:00 hours (no rain), which the differences between the urban and rural temperatures are at their highest [32]. The summer month was chosen since studies in literature showed that $\mathrm{UHI}$ is stronger during the summer months when the air is warmer and UHI is presumed to be higher during nighttime than during the day [33]. The month of May was also being considered because it is the warmest month in Cebu with an average temperature of $30.0^{\circ} \mathrm{C}$ [34]. The route of this study was designed to sample across the urban to rural area. In this study, Colon was chosen to represent the urban are and Lawaan was chosen as the rural area. In order to determine the UHI quantitatively the surface or the air temperature differences of areas classified as urban against an area classified as rural were being measured. The air temperature and humidity was collected using an Extech Hygro-Thermometer SD500 data-logger, which has a temperature range of $0.0-50.0{ }^{\circ} \mathrm{C}$, resolution of $0.1 \%$ and with an accuracy of $\pm 0.8^{\circ} \mathrm{C}$, the relative humidity has a range of $10-90 \%$, resolution of $0.1 \%$ and with an accuracy of $\pm 4 \%$. The instrument was mounted on top of a vehicle with a height of $1.55 \mathrm{~m}$ from the ground and $1.6 \mathrm{~m}$ away (Fig. 2) from the sources of heat (car engine).

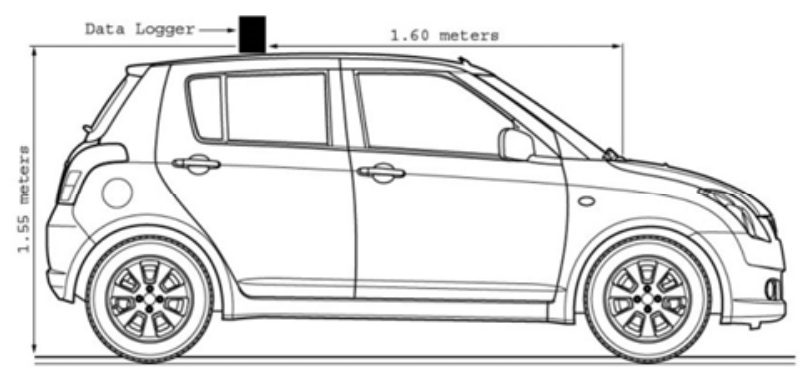

Fig. 2. Location mount of the Data Logger

Wind speed data was also being collected using a portable digital anemometer at a height of $1.55 \mathrm{~m}$ from the ground. Mobile data measurements were collected along the defined route, thus the route began from the Colon obelisk marker (Pari-an) and towards the intersection of Panganiban (Fig. 3). The overall total length of this traverse was roughly 1.15 kilometers long. The mobile route was then retracted back to the obelisk marker so that the average temperature and humidity data could be made of the entire path. An average of 25 temperature and humidity reading was taken from a single travel path. The temperature recorder was set to log temperature and humidity along with the time stamp automatically at 30 seconds interval. The actual traverse time is dictated by traffic speed and traffic light stops. The vehicle was driven at an average speed of $20 \mathrm{~km} / \mathrm{h}$. For each scheduled measurement taken, meteorological conditions were also noted (wind velocity and cloud cover) as this will also have an impact on the air 
temperature data. Ideally, measurements should be carried out simultaneously, but since this is impossible using the mobile measurement techniques [35], the only option was to do the measurements from Colon and to Lawaan in one single traverse [23]. The average sampling difference between the urban (Colon) and the rural (Lawaan) was less than 25 minutes.

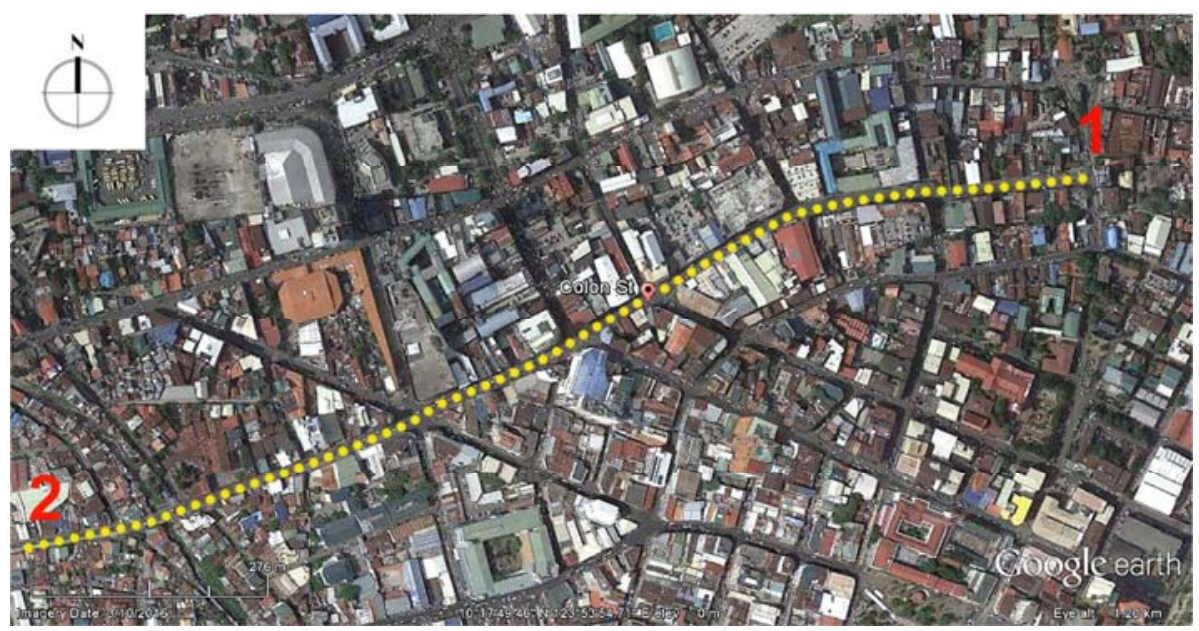

Fig. 3. Map of Colon Street, Cebu City, Cebu, From 'Map of Colon', 10¹7'49.46" N, 1235'54.71" E, Google Earth, Accessed March 3, 2016, Retrieved December 28, 2016, Mobile UHI transect of Colon Street from point 1 (Pari-an) to point 2 (Panganiban).

\section{Results and discussions}

During the experiment, the weather conditions ranged from clear skies to cloudy with mean wind speed at night ranged from 0 to $3 \mathrm{~m} / \mathrm{s}$. These conditions suggest favorable UHI development [23]-[25]. In Table II, the UHI intensity $\left(\Delta T_{U-R}\right)$ was obtained by subtracting the averaged rural and urban temperatures in clear sky conditions. The overall temperature mean value (based on averaged 30 samples) difference between Colon and Lawaan was $\Delta T=1.17^{\circ} \mathrm{C}$. The highest maximum UHI values between the two areas was recorded on May 13 at $\Delta T=2.20^{\circ} \mathrm{C}$ (Table II) while the lowest was recorded on May 15 at $\Delta T=0.30^{\circ} \mathrm{C}$. The current results presented in this study show that urban warming in Colon during the summer nights is higher than that of Lawaan during the summer of May 2016. This indicates local characteristics of the built environment have an important influence. These results derived here are in accordance with those found in previous studies [8], [9], [16], [26]. 
Table II

The data (Temperature, Humidity and Wind speed values) collected during the initial nocturnal UHI study based on an averaged 30 samples

\begin{tabular}{|c|c|c|c|c|c|c|}
\hline \multirow{3}{*}{$\begin{array}{l}\text { Date } \\
(2016)\end{array}$} & \multicolumn{2}{|c|}{ Colon } & \multicolumn{2}{|c|}{ Lawaan } & \multirow[b]{2}{*}{$\begin{array}{l}\text { Mean } \\
\text { Wind } \\
\text { speed }\end{array}$} & \multirow[b]{2}{*}{$\Delta T(\mathrm{u}-\mathrm{r})$} \\
\hline & $\begin{array}{l}\text { Mean } \\
\text { Tempe- } \\
\text { rature }\end{array}$ & $\begin{array}{c}\text { Mean } \\
\text { Humid- } \\
\text { ity }\end{array}$ & $\begin{array}{c}\text { Mean } \\
\text { Tempe- } \\
\text { rature }\end{array}$ & $\begin{array}{c}\text { Mean } \\
\text { Humid- } \\
\text { ity }\end{array}$ & & \\
\hline & ${ }^{\circ} \mathrm{C}$ & $\%$ & ${ }^{\circ} \mathrm{C}$ & $\%$ & $\mathrm{~m} / \mathrm{s}$ & ${ }^{\circ} \mathrm{C}$ \\
\hline May 12 & 31.20 & $71.60 \%$ & 30.4 & $72.90 \%$ & $0.3 \mathrm{~m} / \mathrm{s}$ & 0.80 \\
\hline May 13 & 31.50 & $62.40 \%$ & 29.3 & $69.80 \%$ & $0.3 \mathrm{~m} / \mathrm{s}$ & 2.20 \\
\hline May 14 & 31.20 & $64.00 \%$ & 30.3 & $67.00 \%$ & $0 \mathrm{~m} / \mathrm{s}$ & 0.90 \\
\hline May 15 & 30.00 & $75.00 \%$ & 29.7 & $74.70 \%$ & $0.1 \mathrm{~m} / \mathrm{s}$ & 0.30 \\
\hline May 16 & 31.20 & $66.10 \%$ & 29.6 & $76.70 \%$ & $0.0 \mathrm{~m} / \mathrm{s}$ & 1.60 \\
\hline May 18 & 32.40 & $59.40 \%$ & 30.3 & $67.00 \%$ & $0.0 \mathrm{~m} / \mathrm{s}$ & 2.10 \\
\hline May 19 & 31.20 & $71.10 \%$ & 30.4 & $75.00 \%$ & $2.1 \mathrm{~m} / \mathrm{s}$ & 0.80 \\
\hline May 20 & 32.00 & $64.90 \%$ & 31 & $68.00 \%$ & $0.0 \mathrm{~m} / \mathrm{s}$ & 1.00 \\
\hline May 21 & 31.70 & $68.20 \%$ & 30.3 & $73.30 \%$ & $0.0 \mathrm{~m} / \mathrm{s}$ & 1.40 \\
\hline May 22 & 30.10 & $75.40 \%$ & 29.5 & $73.90 \%$ & $0.3 \mathrm{~m} / \mathrm{s}$ & 0.60 \\
\hline
\end{tabular}

\section{Conclusions and recommendations}

The study showed the presence of nocturnal UHI phenomenon in the densely areas of Colon using the mobile transect method. This also showed initial evidence that the Colon area in Cebu City is slowly developing its own urban heat climate despite the presence of the coastal waters and its cooling effect on the area. The dense built up of buildings, traffic, human activities, urban morphology and meteorological conditions related to climate change can significantly contribute more heat differences. The current results suggest that urban planners and architects need to take into account the possible consequences of urban development and the importance of open green spaces to reduce the development of the urban warming. The health and comfort of the people must be considered in urban development studies in Cebu City. Finally, further study is also required to delve into additional parameters, which is not included in this study. City density, population density, energy consumption, transportation volume, street width may also influence urban warming. No doubt, as the city develops, so too will the effects of UHI. Various mitigations are effective in reducing the UHI but implementations must be careful because different solutions are unique in each city.

\section{Acknowledgements}

This research work has been undertaken as a part of an urban design project with the assistance of the University of San Carlos-Technological Center, the Faculty of Engineering and Information Technology, University of Pécs and Architect Rizzel Magalso, UAP. 


\section{References}

[1] World Population Prospects, Population Division, United Nations, https://esa.un.org/ unpd/wpp/, (last visited 16 June 2016).

[2] Seto K. C., Güneralp B., Hutyara L. R. Global forecasts of urban expansion to 2030 and direct impacts on biodiversity and carbon pools, Proc. Natl. Acad. Sci. U.S.A. Vol. 109, 2012, pp. 16083-16088.

[3] Oke T. R. Towards better scientific communication in urban climate, Theor. Appl. Climatol, Vol. 84, 2006, pp. 179-190.

[4] Landsberg H. E. The urban climate, International Geography, Vol. 28, 1981, pp. 8-9.

[5] Hidalgo J., Pigeon G., Masson V. Urban-breeze circulation during the CAPITOUL experiment: Experimental data analysis approach, Meteor Atmosphere Physics, Vol. 102, 2008a, pp. 223-241.

[6] Zhou D., Liu S., Zhang L., Zhu C. Surface urban heat island in China's 32 major cities: Spatial patterns and drivers, Remote Sens. Environment, Vol. 152, 2014, pp. 51-61.

[7] Clinton N., Gong P. MODIS detected surface urban heat islands and sinks: Global locations and controls, Remote Sens. Environment, Vol. 134, 2013, pp. 294-304.

[8] Peng S. Surface urban heat island across 419 global big cities, Environ. Sci. Technol, Vol. 46, 2012, pp. 696-703.

[9] Howard L. The climate of London deduced from meteorological observations, London, W. Philipps, 1818.

[10] Oke T. R. The energetic basis of the urban heat island, Quart. J. Royal Meteorological Society, Vol. 108, 1982, pp. 1-24.

[11] US Environmental Protection Agency, Heat island mitigation strategies, https://www.epa.gov/heat-islands, (last visited 17 June 2016).

[12] Oke T. R. Urban environments, in: Surface Climates of Canada, Ed. by J. Bailey, Montreal, McGill-Queens University Press, 1997, pp. 303-327.

[13] Svensson M. K. Sky view factor analysis-implications for urban air temperature differences, Meteorol. Appl, Vol. 11, 2004, pp. 201-211.

[14] Ali-Toudert F. A., Mayer H. Numerical study on the effects of aspect ratio and orientation of an urban Street Canyon on outdoor thermal comfort in hot and dry climate, Build Environment, Vol. 41, 2006, pp. 94-108.

[15] Kanda M. Progress in urban meteorology, J. Meterol. Soc. Japan, Vol. 85B, 2007, pp. 363-383.

[16] Schmidlin T. W. The urban heat at Toledo, Ohio, Ohio Journal of Science, Vol. 89, 1989, pp. 38-41.

[17] Steeneveld G. J., Koopmans B. G., Van Hove Heusinkveld L. W. A., Holtslag A. A. M. Quantifying urban heat island effects and human comfort for cities of variable size and urban morphology in the Netherlands, J. Geophys. Res, Vol. 116, No. 20, 2011, pp. 5-6.

[18] Sharifi E., Lehmann S. Comparative analysis of surface urban heat island effect in Central Sydney, Journal of Sustainable Development, Vol. 7, No. 3, 2014, pp. 26-27.

[19] Slingerland J. Mitigation of the urban heat island effect by using water and vegetation, Delft University of Technology, 2012.

[20] Sarkar A., De Ridder K. The urban heat island intensity of Paris: A case study based on a simple urban surface parametrization, Boundary-Layer Meteorol, Vol. 138, 2010, pp. 511-20.

[21] Kim Y., Baik J. Spatial and temporal structure of the urban heat island in Seoul, Journal of Applied Meteorology, Vol. 44, 2005, pp. 591-605.

[22] Voogt J. A. Urban heat islands: Hotter cities, http://www.actionbioscience.org/ environment/voogt.html\#primer, (last visited 22 February 2016). 
[23] Van Hove L. W. A., Jacobs C. M. J., Heusinkveld B. G., Elbers J. A., van Driel B. L. Holtslag A. A. M. Temporal and spatial variability of urban heat island and thermal comfort within the Rotterdam agglomeration, Building and Environment, Vol. 83, 2015, pp. 91-103.

[24] Dwivedi A., Khire M. Measurement technologies for urban heat islands, International Journal of Emerging Technology and Advanced Engineering, Vol. 04, No. 10, 2014, pp. 540-543.

[25] Oke T. R. The urban boundary layer in Montreal, Boundary-Layer Meteor, Vol. 1, 1971, pp. 411-437.

[26] Thomas G., Zachariah E. Urban heat island in a tropical city interlaced by wetland, Journal of Environmental Science and Engineering, Vol. 5, 2011, pp. 234-240.

[27] Thomas G., Sherin A., Shareekul Ansar E. Analysis of urban heat island in Kochi, India, using a modified local climate zone classification, Procedia Environmental Sciences, Vol. 21, 2014, pp. 3-13.

[28] Van Hove L. W. A., Steeneveld G. J., Jacobs C. M. J., Heusinkveld B. G., Elbers J. A., Moors E. J., Holtslag A. A. M. Exploring the urban heat island intensity of Dutch cities: assessment based on a literature review, recent meteorological observation and datasets provide by hobby meteorologists, Alterra Research Report, No. 2170, 2011.

[29] Saaron H., Ben-Dor E., Bitan A., Potchter O. Spatial distribution and microscale characteristics of the urban heat island in Tel-Aviv, Israel, Landscape and Urban Planning, Vol. 48, 1999, pp. 1-18.

[30] Oke T. R., Maxwell G. Urban heat island dynamics in Montreal and Vancouver, Atmospheric Environment, Vol. 9, No. 2, 1975, pp. 191-200.

[31] Javier M. V., Sarricolea P., Moreno-García C. On the definition of urban heat island intensity: The 'rural' reference, Frontiers in Earth Science, Vol. 3, No. 24, 2015, pp. 1-2.

[32] Tereshchenko I. E. Air temperature fluctuations in Guadalajara, Mexico from 1926 to 1994 in relation to urban growth, Int. J. Climatol, Vol. 21, 2001, pp. 483-494.

[33] Arnfield A. J. Two decades of urban climate research: A review of turbulence, exchanges of energy and water, and the urban heat island, Int. J. Climatology, Vol. 23, No. 1, 2003, pp. 1-26.

[34] World Weather \& Climate Information. Weather and Climate: Cebu City, Philippines, Average Monthly, Rainfall (millimeter), Temperatures (Celsius), Humidity, Wind Speed, https://weather-and-climate.com/average-monthly-Rainfall-Temperature-Sunshine,Cebu, Philippines, (last visited 1 March 2016).

[35] Conrads L. A., Van Der Hage J. C. H. A new method of air-temperature measurement in urban climatological studies, Atmospheric Environment, Vol. 5, 1971, pp. 629-635. 